\title{
ХРОНИКА
}

УДК 55

\section{7-я Всероссийская научно-практическая конференция «Геология и полезные ископаемые Западного Урала»}

\section{О.Ю. Мещерякова, П.А. Красильников}

Пермский государственный национальный исследовательский университет, 614990, Пермь, ул. Букирева, 15. E-mail: geolnauka@ gmail.com (Статья поступила в редакиию 14 июня 2017 г.)

23-24 мая 2017 г. на базе Пермского государственного национального исследовательского университета состоялась 37-я Всероссийская научно-практическая конференция с международным участием «Геология и полезные ископаемые Западного Урала». В статье описаны основные моменты работы конференции, освещены затрагиваемые проблемы и тематика докладов, а также подведены итоги.

Ключевые слова: конференция; геология; тематика докладов.

DOI: 10.17072/psu.geol.16.3.300

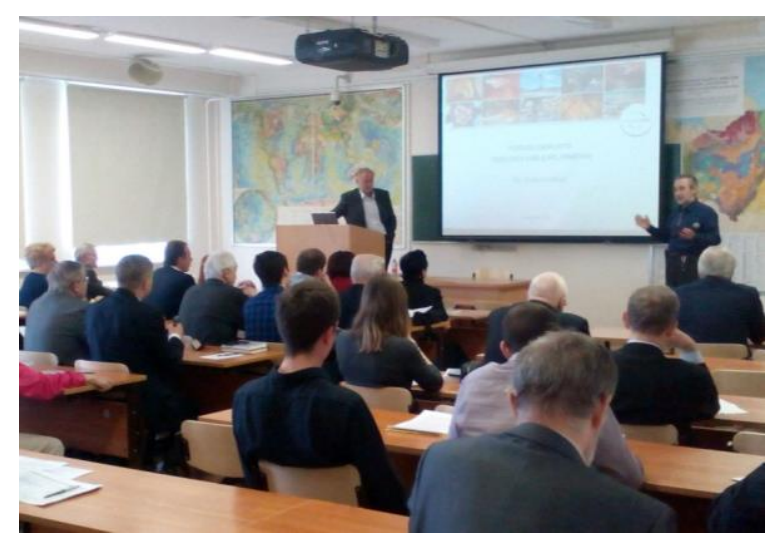

Докладьвает д-р Лукас Волькер

23-24 мая 2017 г. на базе Пермского государственного национального исследовательского университета состоялась 37-я Всероссийская научно-практическая конференция с международным участием «Геология и полезные ископаемые Западного Урала». В работе конференции приняли участие около 60 докладчиков из Германии, Казахстана, России (Екатеринбург, Когалым, Москва, Оренбург, Пермь, Уфа, Ухта) и более чем из 19 научных и производственных организаций (GFZ
German Research Centre for Geosciences, Институт физики Земли РАН, Горный институт УрО РАН, Институт геологии и геохимии УрО РАН, Институт геологии Уфимского научного центра РАН, Российский химико-технологический университет им. Д. И. Менделеева, Ухтинский государственный технический университет, Уральский государственный горный университет, Пермский государственный национальный исследовательский университет (ПГНИУ), Естественнонаучный институт ПГНИУ, Пермский национальный исследовательский политехнический университет (ПНИПУ), Оренбургский научный центр УрО РАН, Институт экологических проблем гидросферы при Оренбургском госуниверситете, ООО «ЛУКОЙЛ-Инжиниринг» «ПермНИПИнефть», ОАО «Когалымнефтегеофизика», ПАО «Уралкалий», АО «КамНИИКИГС», ПАО «Пермьнефтегеофизика», AHO «Центр социальных инициатив “Энергия жизни”».

С приветственными словами выступи- 
ли члены организационного комитета: В.Н. Катаев, декан геологического факультета ПГНИУ и Р.Г. Ибламинов, зав. кафедрой минералогии и петрографии ПГНИУ. На пленарном заседании было заслушано 3 доклада. Доктор Лукас Волькер (ПАО «Уралкалий», г. Березники) сделал доклад на тему «Месторождения солей - геология и разработка», в котором привел подробную характеристику соляных месторождений Канады, Германии и России. Рустем Гильбрахманович Ибламинов представил развитие геохимии в Пермском университете в историческом аспекте. Владимир Петрович Ожгибесов (ПГНИУ, г. Пермь) дал пояснения по общей стратиграфической шкале России для нового стратиграфического кодекса и учебных программ студентов.

Доклады, затрагивающие различные аспекты современной геологии, были разбиты на четыре секции.

1. Минералогия, литология, полезные ископаемые (председатели: Р.Г. Ибламинов, Б.М. Осовецкий).

2. Геология нефти и газа (председатели: Т.В. Карасева, О.Л. Алексеева).

3. Геофизика, геофизические методы (председатели: В.И. Костицын, В.А. Гершанок).

4. Гидрогеология и карст, геоэкология, инженерная геология (председатели: В.Н. Катаев, В.В. Середин).

Конференция способствовала непосредственно общению ученых и специалистов из разных городов и организаций, позволила активизировать существующие и установить новые научные контакты в целях укрепления делового сотрудничества. По итогам работы был издан сборник, в который вошли 56 статей 100 авторов (Геология ..., 2017).

Обсуждения и дискуссии, проходившие в ходе конференции, были посвящены геологии западного склона Урала, Камского Приуралья и прилегающих территорий. Рассмотрены общие вопросы геологии, проблемы прогнозирования месторождений твердых полезных ископаемых, нефти и газа, а также проблемы геофизических методов исследования недр, гидрогеологии, инженерной геологии, карстоведения, экологической геологии.

\section{Библиографический список}

Геология и полезные ископаемые Западного Урала: сб. ст. по материалам Всерос. науч.практ. конф. с междунар. участием / под общ. ред. Р. Г. Ибламинова; Перм. гос. нац. исслед. ун-т. Пермь, 2017. 248 с.

\title{
37th All-Russian Scientific and Practical Conference "Geology and minerals of the Western Urals"
}

\author{
O. Yu. Meshcheryakova, P.A. Krasilnikov
}

Perm State University, 15 Bukireva Str., Perm 614990,Russia

E-mail: geolnauka@gmail.com

On May 23-24, 2017, the 37th All-Russian Scientific and Practical Conference with international participation "Geology of minerals of the Western Urals" was held on the basis of the Perm State University. The article describes the main aspects of the work of the conference, highlights the issues and topics covered in the reports, and summarizes the results.

Keywords: conference; geology; theme of reports

\section{References}

Geologiya i poleznye iskopaemye Zapadnogo
Urala. Materialy konferentsii. R.G. Iblaminov (Ed.). 2017, Perm, PSU, p. 248. (in Russian) 